\title{
Review of T.P. Wiseman's New Men in the Roman Senate
}

\section{Paul Gifford}

In this work, Wiseman sets out to examine the role of the novus homo in the Roman Senate. Rather than attempt to deal with the earlier period of the Republic, an era for which we have little evidence of most senatorial Romans--let alone new men. Wiseman takes as his starting point the passage of the lex Gabinia in $139 \mathrm{BC} .{ }^{1}$ This law imposed a secret ballot, meaning magisterial candidates were no longer bound so tightly to the patronage of the nobilitas, and easing the way for those ambitious and talented enough to forge their own way into the senate.

The book is divided into 5 chapters (excluding the introduction) in which Wiseman attempts to deal with the different elements of the political climate of Rome and how a new man would make their way to office, including both the potential pitfalls and advantages such a candidate might have. It is worth noting that Wiseman draws an explicit divide between two types of 'new man' in his introduction, namely that between men of important families who, upon election, would become the first of their family of consular rank, and those whose ancestors had not held any office and were the first of their lineage to achieve senatorial rank. ${ }^{2}$ While one might be inclined to think this a relatively self explanatory point, in his preface Wiseman underscores how difficult it can be to decipher between someone of provincial and previous senatorial ancestry. ${ }^{3}$ He states that perhaps the most important contribution to make with this work is a complete prosopography of all senators of equestrian and municipal origin. While the prosopography is extensive and heavily researched, it is of little use to anyone who is not a classical scholar, as ultimately the majority of the men contained therein are irrelevant to the grand flow of history, or indeed even to the greater point of Wiseman's narrative. Aside from important figures, who one could read about in greater detail elsewhere, the section is merely a list of names, with their presumed magistracies and the date(s) they held them. It would seem by the importance Wiseman places on this section in his preface that he hopes to have this section become a valuable reference tool for future scholars (in the vein of the Pauly-Wissowa) but one is left wondering why, given its supposed value, this section is tucked away after the appendices in a work which otherwise makes no reference to it.

The main body of the narrative looks separately at the various aspects of the senatorial order and qualifications for office, so it seems only natural that Wiseman would begin with an examination of citizenship in the late republic. The electoral strength of the municipal Italian towns, and the effect which their slowly increasing numbers in the Senate had, are a running theme throughout each of these chapters, as with time the Italian senators would hold more powerful offices and integrate into the power structure at Rome. Wiseman gives the 'thirdgeneration' as a general rule for senatorial acceptance; that is to say, the family would be unlikely to attain senatorial rank until at least the grandson of the first to gain citizenship. ${ }^{4}$

\footnotetext{
1 T. P. Wiseman, New Men in the Roman Senate: 139 BC-14 AD (London: Oxford University Press, 1971$), 4$.

${ }^{2}$ Wiseman, 1.

${ }^{3}$ Ibid., vii.

4 Wiseman, 15.
} 
While this is an interesting observation, Wiseman undermines his point to some extent by spending an equal amount of time providing exceptions to this rule, and uses little space addressing why there would be this difference. Rather, he moves on to address the importance that proximity to the Roman nobility in the capital would provide for the input of new senators. ${ }^{5}$ While he makes a convincing argument, the vast majority of his examples come from the last century and revolves heavily around Arpinum and Picenum. ${ }^{6}$ While he acknowledges that our source base is vastly lacking, he nonetheless applies these examples without explicitly addressing how unusually important some of the home sons of these towns were. ${ }^{7}$ Given the importance of this point to the rest of his argument, this is an unfortunate oversight and detracts somewhat from his later argument.

The next section of the book deals with the role which social interaction played in Roman political workings. As Wiseman points out, “... since Homeric times, the most important relationship [outside family]...had been that between guest friends." Wiseman uses this as the basis for his explanation of the importance of the clientelae system. While the new man was at some disadvantage as compared to the nobility, lacking the vast inherited network of friends and supporters which the nobles were born into, this was mitigated somewhat by a shared social milieu. ${ }^{9}$ Because the Italian nobles and those in Rome itself lived in similar circumstances, they were able to socialize with some ease. ${ }^{10}$ While he elaborates somewhat on the contradiction between this supposed equality and the disdain with which the Senatorial class looked upon new men later in the book, the very real prejudice held towards new men is largely ignored. ${ }^{11}$

The next chapter deals with the monetary requirements and privileges of higher rank. While any man running for public office must have some noticeable measure of wealth prior to commencing any campaign, it was expected that once elected the new magistrate would make a profit out of his time in office, both in a strictly monetary sense as well as through the creation of more clientela. Wiseman explains that by gaining a greater position of authority, there was greater profit to be had, using the example of the money that could be made serving as a duumviror related office. ${ }^{12}$ While the financial information contained in this chapter is valuable, it is scattered and densely written to the point that someone not well acquainted with the bureaucratic structure of the late republic could be easily lost amongst the vast number of similarly named offices.

From here, Wiseman looks at the actual process of getting elected, and it is in this section that he comes back to the point about the importance of friends and neighbours from the first chapter. While the new man might be lacking in the long standing network of alliances that the nobility had, most of the new men of the last century of the Republic were of

${ }^{5}$ Ibid., 30.

${ }^{6}$ Ibid., 31-2.

7 Arpinum is notable as the home of C. Marius and the Tulii Cicerones, and Picenum as the home of Pompeii Strabones.

8 Wiseman, 33.

${ }^{9}$ Ibid., 48.

10 Ibid., 50.

11 Ibid., 103.

12 Ibid., 90. 
wealthy provincial background, and it was to be expected that one's own municipality or hometown would vote for you. ${ }^{13}$ By the late Republic it was no secret that the system had become fairly interbred and corrupt. And while many among the nobilis could claim descent from men of scrupulous moral character, it was often hard to legitimately claim such things for themselves. ${ }^{14}$ Conversely, new men had a greater claim to more traditional Roman values, as being outsiders they were unlikely to be entrenched into this system. ${ }^{15}$ While Wiseman hints at how accurate this claim necessarily was, he does not ever go into any actual critical discussion of it, seemingly accepting that as new men they were unlikely to be so deeply corrupt as the nobility. Given his earlier claim that the upper classes of the Italian municipalities existed in a very similar social circle to those in Rome, this leads to some issue in his argument.

The book finishes with an examination of the offices and the order one must follow towards magisterial grace. While election to the Senate put the new senator in a position of massive power, as compared to the average Roman citizen, amongst their new peers they were still largely unimportant. ${ }^{16}$ Wiseman does an excellent job of explaining the different routes which lay open to the potential magistrate, detailing the longer but safer route of military or urban service versus the riskier (albeit more direct) route of the elected offices. While this section jumps back and forth between the early Principate and the late Republic, it provides a concise and informative look at the pathway a senator would have to follow to gain the consulship.

Overall, this work contains a great deal of valuable information, detailing not only the election process itself for new men but the social background, the voting system, senatorial order, etc. Perhaps due to the relative brevity of the work for the amount of information contained therein, the text can be somewhat disjointed, jumping around temporally with little warning. The first thing which Wiseman declares to the reader is that "the heart of this book is the Prosopography. ${ }^{17}$ " The implication is that the text itself is more of an explanatory note to the names, and it is clear throughout that the author assumes his readers will have a strong background in the Classics, referring to offices and voting procedures often without explanation and seemingly leaving quotations in Latin at random. This last is particularly jarring, as a quotation from one work will be in Latin, and following a brief commentary from Wiseman a further passage from the same work will then be in English. While the work can be of value to the professional classicist, the occasional discrepancies within his argument and the issues with temporality and language make it difficult for anyone outside of the field, and therefore limits its value.

\footnotetext{
13 Wiseman, 124.

14 Ibid., 115.

15 Ibid., 113.

16 Ibid., 153.

${ }^{17}$ Wiseman, vii.
} 